\title{
NILAI PENDIDIKAN KARAKTER \\ PADA KARAKTER TOKOH NADINE ADELLA ULANI \\ DALAM NOVEL ALONE KARYA CHELSEA KARINA
}

\author{
Erlina Zahar ${ }^{1}$, Adzkiya Putri ${ }^{2}$ \\ Program Studi Pendidikan Bahasa dan Sastra Indonesia, \\ Fakultas Keguruan dan Ilmu Pendidikan, Universitas Batanghari, \\ Jambi \\ erlina_zahar@yahoo.co.id \\ adzkiyapoetri@gmail.com
}

\begin{abstract}
This research is aimed at describing the values of educational character of Nadine Adella Ulani character in the novel Alone by Chelsea Karina. This research is qualitative descriptive. The data were taken from the quotations which are related to the aspects of educational character values of the Nadine Adella Ulani character. In analyzing the data, structural approach technique was used. Based on the analysis of the data, it can be found that there are 10 quotations of educational character values of the Nadine Adella Ulani character in the novel Alone by Chelsea Karina. Those 10 aspects included: 8 quotations of honesty value; 12 quotations of bravery value; 2 quotations of trusteeship value; 3 quotations of wisdom value; 3 quotations of responsibility value; 10 quotations of selfreliance; 3 quotations of shame value; 11 quotations of affection value; 3 quotations of beauty value; and 5 quotations of tolerance value. There are 60 quotations which represent those 10 values. The most dominant value occurred in the novel is bravery value, while the least is trusteeship value.
\end{abstract}

Keywords: Educational Character Values, Character, Alone Novel

\footnotetext{
${ }^{1}$ Dosen Program Studi Pendidikan Bahasa dan Sastra Indonesia, Fakultas Keguruan dan Ilmu Pendidikan, Universitas Batanghari, Jambi

${ }^{2}$ Mahasiswa Program Studi Pendidikan Bahasa dan Sastra Indonesia, Fakultas Keguruan dan Ilmu Pendidikan, Universitas Batanghari, Jambi

Nilai Pendidikan Karakter pada Karakter Tokoh Nadine Adella Ulani dalam Novel Alone Karya Chelsea Karina
} 


\section{PENDAHULUAN}

Salah satu wujud karya seni manusia adalah karya sastra. Karya sastra merupakan salah satu karya seni yang disukai oleh masyarakat. Sebagai bacaan yang disukai masyarakat, sastrawan mengungkapkan isu-isu kehidupan manusia sebagai objek karya sastranya. Fenomena kehidupan manusia dapat dijadikan sebagai inspirasi bagi sastrawan untuk dituliskan menjadi karya sastra. Peristiwa-peristiwa kehidupan manusia yang terjadi di alam nyata kemudian dikreasikan oleh sastrawan melalui kreativitas seninya hingga tercipta karya sastra. Menurut Rahima (2016:1) kelahiran sebuah karya sastra bersumber dari kehidupan manusia yang bertata nilai. Hal ini dapat memberi sumbangan bagi terbentuknya tata nilai yang baik dalam masyarakatnya. Tata nilai ini tercermin dalam sebuah karya sastra.

Secara garis besar, karya sastra memiliki tiga jenis. Ketiga jenis karya sastra tersebut yakni, puisi, prosa, dan drama. Jenis karya sastra prosa berbagai pula wujudnya, yaitu cerpen, novelet, dan novel (Nurgiyantoro, 2012:9). Sebagai jenis karya prosa, novel merupakan jenis prosa yang paling popular. Popularitas karya novel terlihat dari lakunya buku novel pada bursa buku. Novel merupakan bacaan yang sangat digemari oleh masyarakat, baik dari remaja, orang dewasa, sampai orang tua sekalipun.

Novel merupakan suatu karangan fiktif imajinatif berbentuk prosa yang ditulis oleh seorang pengarang dengan menyuguhkan rangkaian cerita kehidupan seseorang dengan orang di sekitarnya sembari memperlihatkan atau menorehkan watak dan sifat pelaku di dalam cerita (Nurgiyantoro, 2012: 10). Popularitas novel semakin terlihat jelas dengan hadirnya para penulis kreatif yang menghadirkan buku bacaan dengan memasukkan nilai-nilai kehidupan yang membuat pembaca semakin tertarik untuk membacanya. Novel yang mengisahkan tentang sisi nilai kehidupan manusia diantaranya adalah novel Alone karya Chelsea Karina.

Novel Alone karya Chelsea Karina menyuguhkan nilai kehidupan yang artistik, termasuk di dalamnya nilai pendidikan karakter yang terdapat pada karakter tokoh Nadine Adella Ulani. Nilai pendidikan karakter merupakan sesuatu yang berguna dalam menumbuhkan dan mengembangkan potensi yang ada dalam diri manusia, baik itu sikap, sifat, emosi maupun pengetahuan. Pentingnya nilai pendidikan karakter dalam diri manusia, ditujukan untuk membuat manusia menjadi pribadi yang memiliki kecerdasan, berakhlak, berkarakter, berilmu, kreatif, mandiri, dan menjadi warga negara yang demokratis serta bertanggung jawab.

Pada saat ini masyarakat Indonesia cendrungan mengikuti gaya hidup baru yang trendy dan menempatkan nilai-nilai baru dalam keberhasilan. Oleh karena itu, terjadi pergeseran nilai etika dalam kehidupan berbangsa dan bernegara yang mengenyampingkan nilai-nilai pendidikan karakter. Today's phenomenon shows that Indonesians tend to follow a trendy new lifestyle. With theformer value of togetherness, now dominated by individualistic values, spiritual valuesare replaced by material elements (Rahima, 2018:754). Pandangan ini menunjukkan bahwa adanya fenomena gaya hidup masyarakat Indonesia yang mementingkan nilai-nilai individual dan material dibandingkan nilai moral dan nilai agama.

Hal ini terlihat dari berbagai aktivitas manusia baik yang kita saksikan di televisi maupun yang kita baca beritanya di surat kabar. Seperti berita yang ditayangkan di laman Instagram

Nilai Pendidikan Karakter pada Karakter Tokoh Nadine Adella Ulani dalam Novel Alone Karya Chelsea Karina 
Kabar Kampung Kito. Maraknya tertangkap pasangan yang bukan suami istri di sebuah kos-kosan yang kemudian digrebek oleh aparat dalam kegiatan razia rutin. Hal ini mengindikasikan bahwa nilai-nilai karakter telah tergerus. Fenomena di atas, menjadikan tolak ukur bahwa terlihat jelas nilai karakter dalam diri manusia mulai tergerus. Hal tersebut membuat peneliti ingin mengkaji lebih dalam tentang nilai karakter dalam diri manusia, khususnya nilai pendidikan karakter. Dengan mengetahui dan mempelajari nilai pendidikan karakter, diharapkan sikap, karakter dan moral di dalam diri manusia menjadi lebih baik sehingga dapat memberikan sumbangsih positif kepada orang lain atau masyarakat. Salah satu bacaan yang menyuguhkan nilai-nilai karakter manusia adalah novel Alone karya Chelsea Karina. Berdasarkan paparan di tersebut, maka penelitian ini penting untuk diteliti.

Penelitian ini berfokus kepada tiga belas nilai pendidikan karakter yang meliputi, nilai jujur, berani, amanah, adil, bijaksana, tanggung jawab, disiplin, mandiri, malu, kasih sayang, indah, mudah toleran, dan cinta bangsa (Nashir, 2013:71-95).

Berdasarkan fokus penelitian tersebut, maka penelitian ini berusaha untuk menjawab beberapa pertanyaan penelitian, sebagai berikut.

1. Bagaimanakah aspek nilai jujur dalam karakter tokoh Nadine Adella Ulani pada novel Alone karya Chelsea Karina?

2. Bagaimanakah aspek nilai berani dalam karakter tokoh Nadine Adella Ulani pada novel Alone karya Chelsea Karina?

3. Bagaimanakah aspek nilai amanah dalam karakter tokoh Nadine Adella Ulani pada novel Alone karya Chelsea Karina?
4. Bagaimanakah aspek nilai adil dalam karakter tokoh Nadine Adella Ulani pada novel Alone karya Chelsea Karina?

5. Bagaimanakah aspek nilai bijaksana karakter dalam tokoh Nadine Adella Ulani pada novel Alone karya Chelsea Karina?

6. Bagaimanakah aspek nilai tanggung jawab dalam karakter tokoh Nadine Adella Ulani pada novel Alone karya Chelsea Karina?

7. Bagaimanakah aspek nilai disiplin dalam karakter tokoh Nadine Adella Ulani pada novel Alone karya Chelsea Karina?

8. Bagaimanakah aspek nilai mandiri dalam karakter tokoh Nadine Adella Ulani pada novel Alone karya Chelsea Karina?

9. Bagaimanakah aspek nilai malu dalam tokoh Nadine Adella Ulani pada novel Alone karya Chelsea Karina?

10. Bagaimanakah aspek nilai kasih sayang dalam karakter tokoh Nadine Adella Ulani pada novel Alone karya Chelsea Karina?

11. Bagaimanakah aspek nilai keindahan dalam karakter tokoh Nadine Adella Ulani pada novel Alone karya Chelsea Karina?

12. Bagaimanakah aspek nilai toleransi dalam karakter tokoh Nadine Adella Ulani pada novel Alone karya Chelsea Karina?

13. Bagaimanakah aspek nilai cinta bangsa dalam karakter tokoh Nadine Adella Ulani pada novel Alone karya Chelsea Karina?

Adapun tujuan penelitian ini adalah untuk mendeskripsikan nilai-nilai pendidikan karakter pada karakter tokoh Nadine Adella Ulani dalam novel Alone karya Chelsea Karina, yang meliputi 13 aspek.

Penelitian ini diharapkan memiliki beberapa manfaat, yang

Nilai Pendidikan Karakter pada Karakter Tokoh Nadine Adella Ulani dalam Novel Alone Karya Chelsea Karina 
meliputi manfaat parktis dan manfaat teoretis. Secara teoretis, manfaat dari penelitian ini adalah dapat menambah pengetahuan mengenai pembelajaran nilai pendidikan karakter. Penelitian ini memberikan sumbangan bagi perkembangan ilmu pengetahuan khusunya di bidang bahasa dan sastra sehingga dapat digunakan sebagai landasan untuk penelitian selanjutnya, khusunya nilai pendidikan karakter seorang tokoh dalam novel. Secara praktis penelitian ini dapat dapat bermanfaat pihak-pihak terkait, yaitu:

1. Peneliti sendiri, penelitian ini berguna untuk memperkaya wawasan peneliti, terutama pemahaman tentang nilai pendidikan karakter.

2. Peneliti selanjutnya, penelitian ini dapat dijadikan sebagai informasi awal untuk penelitian yang sejalan dengan penelitian ini.

3. Pembaca, penelitian ini diharapkan dapat memberikan pemahaman dan pengetahuan tentang nilai pendidikan karakter.

4. Guru dapat menjadikan penelitian ini sebagai bahan ajar bagi peserta didik khusunya di bidang sastra.

5. Siswa atau pelajar, penelitian ini dapat dijadikan sebagai pelajaran tambahan ilmu pengetahuan khususnya tentang nilai pendidikan karakter yang ada pada suatu tokoh.

\section{METODE PENELITIAN}

Dalam penelitian sastra terdapat beberapa sudut pandang atau pendekatan dalam menganalisisnya. Menurut Rahima (2016:1) perbedaan sudut pandang atau pendekatan yang digunakan peneliti akan memunculkan adanya berbagai jenis penelitian sastra. Jenis penelitian ini merupakan penelitian kualitatif dengan metode deskriptif. Metode deskriptif kualitatif adalah suatu metode atau cara yang digunakan seorang peneliti dengan menguraikan kata-kata bukan angka-angka dan lebih mengutamakan penghayatan yang mendalam terhadap objek yang dikaji.

Data merupakan kumpulan dari semua informasi yang akan diseleksi sebagai bahan analisis (Siswantoro, 2010:70). Data penelitian ini adalah data yang diseleksi atau diperoleh langsung dari sumbernya tanpa perantara, yakni kutipan-kutipan yang berkaitan dengan nilai-nilai pendidikan karakter pada karakter tokoh Nadine Adella Ulani yang ada pada novel Alone karya Chelsea Karina. Sumber data dalam penelitian ini adalah novel Alone karya Chelsea Karina.

Pengumpulan data pada penelitian ini menggunakan teknik dokumentasi dan studi literatur yang difokuskan untuk menganalisis nilai pendidikan karakter dalam novel Alone karya Chelsea Karina. Adapun langkah-langkah dalam pengumpulan data pada penelitian ini sebagai berikut (Levi-Strauss dalam Rafiek, 2012: 75).

1. Peneliti membaca keseluruhan secara cermat, teliti, dan berulang kali, isi keseluruhan novel Alone karya Chelsea Karina.

2. Peneliti membagi cerita menjadi beberapa kelompok. Hal ini dimaksudkan untuk mempermudah peneliti mengelompokkan fokus bacaan yang hendak dikaji.

3. Peneliti memahami isi novel yang berkaitan atau berkenaan dengan aspek-aspek nilai pendidikan karakter. Hal ini dilakukan untuk memudahkan dalam mengidentifikasi aspek-aspek nilai pendidikan karakter dalam novel Alone karya Chelsea Karina.

4. Peneliti memperhatikan dan menandai kata-kata, maupun kalimatkalimat yang bersingggungan dan berkenaan dengan nilai pendidikan karakter.

5. Peneliti mencatat data yang diperoleh dari penandaan kata-kata maupun

Nilai Pendidikan Karakter pada Karakter Tokoh Nadine Adella Ulani dalam Novel Alone Karya Chelsea Karina 
kalimat-kalimat yang bersinggungan atau berkenaan dengan aspek nilai pendidikan karakter.

6. Setelah data-data terkumpul, peneliti mengklasifikasikan data sesuai dengan kepentingan penelitian, yakni nilai pendidikan karakter yang ada dalam novel Alone karya Chelsea Karina.

Teknik analisis data merupakan serangkaian kegiatan untuk memaparkan data-data deskriptif. Teknik ini dilakukan setelah semua data-data terkumpul dari novel Alone karya Chelsea Karina. Langkah dalam analisis data diuraikan sebagai berikut.

1. Data yang sudah dikelompokkan berdasarkan aspek nilai pendidikan karakter, kemudian dimuat ke dalam tabel tabulasi data.

2. Setelah ditabulasi, langkah berikutnya adalah menginterpretasikan data.

3. Setelah diinterpretasikan, data dianalisis dengan menggunakan teori.

4. Setelah itu, peneliti melakukan pengabsahan data dengan cara; pertama, pengabsahan data dengan teori; kedua, pengabsahan data dengan metode; ketiga, pengabsahan data dengan ahli atau pembimbing.

5. Langkah berikutnya yakni peneliti merumuskan kesimpulan dari kegitan yang telah dilakukan.

\section{HASIL DAN PEMBAHASAN}

Berdasarkan hasil analisis data yang telah dilakukan, maka tergambar bahwa tokoh Nadine Adella Ulani memiliki karakter yang kuat. Hal ini terlihat dari sepuluh aspek nilai pendidikan karakter ada pada dirinya yang tergambar dalam kutipan-kutipan di dalam novel Alone karya Chelsea Karina.

\section{Aspek Nilai Jujur pada Karakter Tokoh Nadine Adella Ulani dalam Novel Alone Karya Chelsea Karina}

\section{Kutipan 1}

Kevin menatap Della dengan tajam. "Lo cerita sama Papa tentang balapan liar?", “Iya". "Lo gila ya?" Kevin bertanya dengan tak percaya. (Alone: 26).

Kutipan 1 tersebut menggambarkan karakter seorang Della yang jujur. Della memberitahukan kebenaran yang terjadi kepada ayahnya tentang kakaknya yang mengikuti balapan liar. Berdasarkan kutipan tersebut, terlihat karakter jujur yang dimiliki Della adalah untuk kebaikan kakaknya sendiri. Hal ini sesuai dengan pendapat Al-Hufy (dalam Nashir, 2013: 71) yang menyatakan bahwa sikap jujur merupakan sikap yang sesuai antara perkataan dan perbuatan. Perkataan dan perbuatan yang dilakukan secara jujur, sesuai dengan kenyataan akan membuat seseorang menjadi pribadi yang dapat dipercayai oleh oranglain.

\section{Aspek Nilai Berani pada Karakter Tokoh Nadine Adella Ulani dalam Novel Alone Karya Chelsea Karina}

\section{Kutipan 2}

Della melajukan mobilnya menuju rumah orangtuanya, ia siap dengan masalah yang akan ia hadapi jika mereka marah ketika melihatnya kembali menginjakkan kaki di rumah besar tersebut. Ia sangat merindukan orangtuanya. (Alone: 54).

Kutipan yang bercetak tebal di atas merupakan gambaran seorang Della yang berani mengambil suatu keputusan dan sebuah tindakan. Ia memberanikan diri dalam mengambil suatu keputusan dengan datang kembali ke rumah orangtuanya yang sudah jelas berseteru dengannya dan siap menerima konsekuensinya. Berdasarkan kutipan 2

Nilai Pendidikan Karakter pada Karakter Tokoh Nadine Adella Ulani dalam Novel Alone Karya Chelsea Karina 
tersebut, karakter berani yang dimiliki Della menyangkut antara keberanian di dalam dirinya atas tindakan yang akan di lakukannya. Hal ini sesuai dengan pendapat Hamka (dalam Nashir, 2013:73) yang menyatakan bahwa kebranian merupakan sikap yang berada di dalam diri seseorang guna dipergunakan untuk mengambil langkah dalam setiap hal yang akan dilakukan. Keberanian merupakan sesuatu yang dilandasi atas segala pertimbangan yang matang dan kekuatan hati yang kokoh.

\section{Aspek Nilai Amanah pada Karakter Tokoh Nadine Adella Ulani dalam Novel Alone Karya Chelsea Karina}

\section{Kutipan 3}

Orang itu menggeleng. Ia mendekati Della dengan pisau digenggamannya. Lalu berkata, "Lo mau tau cara supaya dia selamat?", Della mengangguk dan jujur, ia mulai takut sekarang. Orang itu mendekat dan berbisik, membuat Della memejamkan matanya untuk berpikir sejenak. Akhirnya, dengan berat hati ia mengangguk (Alone: 205).

Kutipan yang bercetak tebal di atas merupakan gambaran seorang Della yang amanah dalam mengemban suatu tugas dari seseorang. Secara tersirat kutipan di atas menjelaskan bahwa Della adalah seorang yang amanah, terlihat dari kutipan kalimat yang mengisyaratkan Della harus memenuhi suatu kewajiban dan perintah. Terlihat bahwa amanah yang harus di emban oleh Della walaupun di satu sisi ia adalah pihak yang di rugikan. Berdasarkan kutipan 3 tersebut, karakter amanah yang dimiliki Della menyangkut titipan pesan yang nantinya diaplikasikan secara tindakan. Hal ini sesuai dengan teori Depdiknas (dalam dalam Nashir, 2013: 76) yang menyatakan bahwa amanah merupakan suatu kepercayaan atau titipan yang diberikan seseorang kepada orang lain. Seseorang yang telah diberikan kepercayaan oleh orang lain baik itu untuk mengemban suatu tugas maupun menitipkan pesan disebut sebagai seseorang yang amanah atau dapat dipercaya.

\section{Aspek Nilai Bijaksana pada Karakter Tokoh Nadine Adella Ulani dalam Novel Alone Karya Chelsea Karina}

\section{Kutipan 4}

"Udahlah, sekarang semua terserah lo aja. Mau lo gimana? Putus?”. Della menggeleng dengan cepat dan langsung memeluk Fatih. "Aku mohon, jangan pernah bilang putus lagi, dia bukan siapa-siapa aku, Tih". (Alone: 70).

Kutipan yang bercetak tebal di atas merupakan gambaran seorang Della yang bijaksana dalam mengambil suatu keputusan dan sebuah tindakan yang tepat. Ia mengambil suatu keputusan yang tepat dengan langsung menggelengkan kepalanya yang bermaksud menolak ajakan Fatih untuk putus dan langsung memberikan pernyataan yang jujur. Sikap bijaksana yang dilakukan Della menjadikan ia sebagai seorang yang bijak dalam setiap tindakan yang dilakukan dan menjadikan ia sebagai manusia yang pandai mengatur emosi serta sikap. Hal ini sesuai dengan pendapat Nashir (2013: 80) bahwa Bijaksana merupakan pengambilan sikap yang tegas dan benar. Manusia yang bijak adalah manusia yang pandai mengatur emosi, sikap, keputusan, dan segala tindakan yang dilakukan.

\section{Aspek Nilai Tanggung Jawab pada Karakter Tokoh Nadine Adella}

Nilai Pendidikan Karakter pada Karakter Tokoh Nadine Adella Ulani dalam Novel Alone Karya Chelsea Karina 


\section{Ulani dalam Novel Alone Karya Chelsea Karina}

(Kutipan 5

"Ya sudah, silahkan kamu hormat ke tiang bendera selama satu jam pelajaran". Raut wajah Della kembali cerah. Ia tersenyum dan keluar dari ruangan untuk menjalankan hukumannya. (Alone: 38).

Kutipan yang bercetak tebal di atas merupakan gambaran seorang Della yang bertanggung jawab atas segala tindakan yang ia lakukan. Dari kutipan tersebut, diketahui ia bertanggung jawab atas tindakan yang telah dilakukannya dan bersedia di hukum akibat kelakuannya tersebut. Sikap tanggung jawab yang dilakukan Della menjadikan ia sebagai pribadi yang mempunyai kesadaran serta bertanggung jawab atas segala tindakan yang dilakukannya. Hal ini sesuai dengan pendapat Nashir (2013: 82). bahwa tanggung jawab merupakan sikap yang harus dimiliki oleh seseorang karena dapat memberikan kesadaran untuk diri sendiri terhadap suatu tindakan yang dilakukan. Tanggung jawab berarti kesadaran diri sendiri atas penyelesaian tugas dan kewajiban, baik itu dari diri sendiri, maupun orang lain.

\section{Aspek Nilai Mandiri pada Karakter Tokoh Nadine Adella Ulani dalam Novel Alone Karya Chelsea Karina}

Kutipan 6

Gue tinggal sendiri. Kenapa? Karena orangtua gue udah nggak peduli lagi sama gue. Lebih tepatnyaa mungkin gue dibuang. (Alone: 3 ).

Kutipan yang bercetak tebal di atas merupakan gambaran seorang Della yang mandiri dan tidak bergantung kepada orang lain. Ia hidup sendirian karena tidak dipedulikan oleh keluarganya.
Seseorang yang tinggal sendiri otomatis mengurusi segala hal secara personal. Sikap mandiri yang ada di dalam diri Della menjadikan ia sebagai pribadi yang dapat mengurusi segala hal tanpa bantuan orang lain dan menjadikan ia sebagai pribadi yang pandai dan handal dalam segala aspek. Hal ini sesuai dengan pendapat Nashir (2013:86) bahwa mandiri merupakan langkah yang diambil seseorang untuk tidak banyak bergantung kepada orang lain tentang suatu hal. Sikap mandiri yang terus di asah akan dapat menumbuhkan serta mengembangkan kemampuan diri dalam menghadapi suatu persoalan, sehingga suatu persoalan bisa diselesaikan tanpa bantuan orang lain dan membuat seseorang itu lebih unggul.

\section{Aspek Nilai Malu pada Karakter Tokoh Nadine Adella Ulani dalam Novel Alone Karya Chelsea Karina}

\section{Kutipan 7}

"Ih gue malu Fatih!". Fatih merangkul Della. "Nggak usah malu. Btw, aku serius tadi". (Alone: 16).

Kutipan yang bercetak tebal tersebut merupakan gambaran seorang Della yang memiliki sikap malu. Ia malu jika melakukan kesalahan maupun tindakan yang tidak patut dilakukan. Seseorang yang memiliki rasa malu dalam dirinya akan menjadikan seseorang itu taat dan tidak berani melakukan hal yang tercela. Hal ini sesuai dengan pendapat Al-Hufy (dalam Nashir, 2013: 87) malu merupakan suatu sikap yang tertanam dalam diri seseorang. Malu didefinisikan sebagai suatu perasaan yang tidak enak terhadap perbuatan maupun perkataan yang tidak patut.

\section{Aspek Nilai Kasih Sayang pada Karakter Tokoh Nadine Adella}

Nilai Pendidikan Karakter pada Karakter Tokoh Nadine Adella Ulani dalam Novel Alone Karya Chelsea Karina 


\section{Ulani dalam Novel Alone Karya Chelsea Karina}

Kutipan 8

Papa itu Ketua Yayasan di sekolah gue. Kadang kalo ada acara besar dan Papa harus dateng gue seneng banget, karena akhirnya gue bisa ketemu sama dia. Papa orang yang paling benci sama gue. Tapi mau gimana juga sikap dia ke gue, gue ga bisa menampik kalau gue sayang sama dia. (Alone: 4).

Kutipan yang bercetak tebal tersebut merupakan gambaran seorang Della yang memiliki sikap kasih sayang. Walaupun ia dibenci oleh ayahnya sendiri, ia tetap menyayanginya. Kasih sayang menghadirkan sentuhan kasih yang dapat mempererat hubungan seseorang, walaupun di satu sisi orang tersebut tidak menyayangi kita, seperti yang terjadi antara Della dan ayahnya. Sikap kasih sayang yang ada pada diri Della menjadikan ia sebagai seorang yang memiliki sentuhan kasih terhadap orang lain. Hal ini sesuai dengan pendapat Nashir (2013: 90) bahwa kasih sayang merupakan ungkapan perasaan suka, nyaman, berbagi kasih kepada orang lain. Kasih sayang menghadirkan sentuhan kasih yang dapat mempererat hubungan seseorang, dan merupakan bagian hidup manusia yang paling penting.

\section{Nilai Indah pada Karakter Tokoh Nadine Adella Ulani dalam Novel Alone Karya Chelsea Karina}

Kutipan 9

Della menatap gedung-gedung tinggi yang berada di kanan maupun kiri jalan. Terkadang ia merasa kagum sendiri dengan apa yang ia lihat. (Alone: 9).

Kutipan yang bercetak tebal di atas menggambarkan karakter indah yang ada pada diri Della. Ketika Della melihat gedung-gedung tinggi di hadapannya, ia merasasakan keindahan dan merasa kagum dengan apa yang ia lihat. Sesuatu yang indah akan menyejukkan hati seseorang yang melihatnya. Hal ini sesuai dengan pendapat Nashir (2013: 92) bahwa indah merupakan suatu hal yang dirasakan seseorang ketika seseorang itu sedang melihat sesuatu yang bagus atau menyejukkan hati. Sesuatu yang indah, menawan, cantik, enak dipandang, akan memunculkan atau memancarkan sesuatu di hati dan pikiran yang melihatnya.

\section{Aspek Nilai Toleran pada Karakter Tokoh Nadine Adella Ulani dalam Novel Alone Karya Chelsea Karina}

\section{Kutipan 10}

Semua teman Della masuk ke apartemen Della. Hari ini selepas pulang sekolah, mereka langsung menuju apartemen Della. Mereka bertingkah seolah-olah apartemen Della adalah milik mereka karena seringnya mereka datang ke sini. (Alone: 12).

Kutipan yang bercetak tebal di atas merupakan gambaran seorang Della yang memiliki sikap toleran. Ia menghargai dan menerima sesuatu yang yang berbeda terhadap dirinya. Della menghargai sikap temannya yang selalu bertingkah seolah-olah apartemen Della adalah miliknya. Sikap toleransi yang dimiliki oleh Della membuat kehidupannya damai dan dengan menerima perbedaan antara dirinya dengan orang lain, maka akan membuat sikap toleransinya semakin kokoh dan kuat. Hal ini sesuai dengan pendapat Nashir (2013: 93) bahwa toleran sering diartikan sebagai suatu sikap menghargai suatu hal. Adanya sikap toleran dalam diri setiap manusia, membuat seseorang

Nilai Pendidikan Karakter pada Karakter Tokoh Nadine Adella Ulani dalam Novel Alone Karya Chelsea Karina 
mampu menghargai segala bentuk yang berbeda dari dirinya sendiri. Sikap yang dapat menerima suatu perbedaan dan keanekaragaman dalam diri seseorang itu sangat penting, karena dengan adanya suatu perbedaan, dapat menjadikan diri seseorang lebih bisa menghargai sesuatu.

\section{SIMPULAN}

Berdasarkan hasil penelitian dan pembahasan, dapat diperoleh kesimpulan bahwa pada karakter tokoh Nadine Adella Ulani dalam novel Alone karya Chelsea Karina, terkandung sepuluh aspek nilai pendidikan karakter yaitu, aspek nilai jujur, aspek nilai berani, aspek nilai amanah, aspek nilai bijaksana, aspek nilai tanggung jawab, aspek nilai mandiri, aspek nilai malu, aspek nilai kasih sayang, aspek nilai indah, dan aspek nilai toleran yang akan disimpulkan dan dijabarkan sebagai berikut.

1. Aspek nilai jujur pada karakter tokoh Nadine Adella Ulani dapat terlihat dan tergambar dari karakter di dalam dirinya yang selalu jujur di dalam situasi dan kondisi apapun, yang terlihat dari kutipan-kutipan yang menggambarkan bahwa ia jujur. Kutipan-kutipan yang menunjukkan bahwa tokoh Nadine Adella Ulani memiliki karakter jujur ditemukan dalam novel Alone karya Chelsea Karina sebanyak 11 kutipan.

2. Aspek nilai berani pada karakter tokoh Nadine Adella Ulani dapat terlihat dan tergambar dari karakter di dalam dirinya yang selalu berani di dalam situasi dan kondisi apapun, yang terlihat dari kutipan-kutipan yang menggambarkan bahwa ia berani. Kutipan-kutipan yang menunjukkan bahwa tokoh Nadine Adella Ulani memiliki karakter berani ditemukan dalam novel Alone karya Chelsea Karina sebanyak 10 kutipan.
3. Aspek nilai amanah pada tokoh Nadine Adella Ulani dapat terlihat dan tergambar dari karakter di dalam dirinya yang selalu dapat dipercaya oleh oranglain. Kutipan-kutipan yang menunjukkan bahwa tokoh Nadine Adella Ulani memiliki karakter amanah ditemukan dalam novel Alone karya Chelsea Karina sebanyak 2 kutipan.

4. Aspek nilai bijaksana pada karakter tokoh Nadine Adella Ulani dapat terlihat dan tergambar dari karakter di dalam dirinya yang selalu bijaksana dalam situasi dan kondisi apapun. Kutipan-kutipan yang menunjukkan bahwa tokoh Nadine Adella Ulani memiliki karakter bijaksana ditemukan dalam novel Alone karya Chelsea Karina sebanyak 3 kutipan.

5. Aspek nilai tanggung jawab pada karakter tokoh Nadine Adella Ulani dapat terlihat dan tergambar dari karakter di dalam dirinya yang selalu bertanggung jawab atas segala hal yang telah dilakukannya. Kutipankutipan yang menunjukkan bahwa tokoh Nadine Adella Ulani memiliki tanggung jawab ditemukan dalam novel Alone karya Chelsea Karina sebanyak 2 kutipan.

6. Aspek nilai mandiri pada tokoh Nadine Adella Ulani dapat terlihat dan tergambar dari karakter di dalam dirinya yang selalu mengambil langkah untuk tidak banyak bergantung kepada orang lain. Kutipan-kutipan yang menunjukkan bahwa tokoh Nadine Adella Ulani mandiri ditemukan dalam novel Alone karya Chelsea Karina sebanyak 10 kutipan.

7. Aspek nilai malu pada tokoh Nadine Adella Ulani dapat terlihat dan tergambar dari karakter di dalam dirinya yang selalu malu atas segala hal maupun perbuatan yang tidak patut dilakukan. Kutipan-kutipan yang

Nilai Pendidikan Karakter pada Karakter Tokoh Nadine Adella Ulani dalam Novel Alone Karya Chelsea Karina 
menunjukkan bahwa tokoh Nadine Adella Ulani memiliki malu ditemukan dalam novel Alone karya Chelsea Karina sebanyak 3 kutipan.

8. Aspek nilai kasih sayang pada tokoh Nadine Adella Ulani dapat terlihat dan tergambar dari karakter di dalam dirinya yang selalu sayang dan mencintai keluarganya. Kutipankutipan yang menunjukkan bahwa tokoh Nadine Adella Ulani memiliki kasih sayang ditemukan dalam novel Alone karya Chelsea Karina sebanyak 11 kutipan.

9. Aspek nilai indah pada tokoh Nadine Adella Ulani dapat terlihat dan tergambar dari karakter di dalam dirinya saat ia merasakan dan melihat sesuatu yang elok, cantik, dan menyejukkan hati serta raganya. Kutipan-kutipan yang menunjukkan bahwa tokoh Nadine Adella Ulani memiliki nilai indah ditemukan dalam novel Alone karya Chelsea Karina sebanyak 3 kutipan.

10. Aspek nilai toleran pada tokoh Nadine Adella Ulani dapat terlihat dan tergambar dari karakter di dalam dirinya saat ia menyikapi suatu hal. Kutipan-kutipan yang menunjukkan bahwa tokoh Nadine Adella Ulani memiliki rasa toleran ditemukan dalam novel Alone karya Chelsea Karina sebanyak 5 kutipan.

Berdasarkan uraian di atas, dapat disimpulkan bahwa pada tokoh Nadine Adella Ulani dalam novel Alone karya Chelsea Karina terdapat 60 aspek nilai pendidikan karakter. Aspek nilai pendidikan karakter tersebut memiliki peran dan pesan yang baik untuk dipelajari dan di contoh oleh masyarakat dalam kehidupan sehari-hari.

\section{Saran}

Beberapa saran yang dapat
disampaikan terkait dengan hasil
penelitian ini, sebagai berikut.

1. Bagi pembaca, hendaknya setelah membaca dan memahami hasil penelitian ini dapat menjadikan serta meningkatkan karakter diri menjadi lebih baik.

2. Bagi sastrawan, hendaknya dapat menulis karya-karya sastra yang lebih bermanfaat guna meningkatkan karakter hidup manusia.

3. Hasil penelitian ini hendaknya menjadi bahan ajar sastra bagi guru dalam mengajarkan materi pembelajaran karakter di sekolah.

4. Bagi siswa atau pelajar, hendaknya setelah membaca dan memahami penelitian ini, dapat memberikan sumbangsih ilmu pengetahuan dan pembelajaran bagi perkembangan dan perbaikan karakter siswa.

\section{DAFTAR PUSTAKA}

Karina, Chelsea. (2019). Alone. Depok: RANS Publisher.

Nashir, Haedar. (2013). Pendidikan Karakter Berbasis Agama dan budaya. Yogyakarta: Multi Presindo.

Nurgiyantoro, Burhan. (2012). Teori Pengkajian Fiksi. Yogyakarta: Gajah Mada University.

Rafiek, M. (2010). Teori Sastra: Kajian Teori dan Praktik. Bandung: Ritika Adiyatama.

Rahima, A. (2017). Literature Receptio (a Conceptual Overview). Jurnal Ilmiah Dikdaya, 6(1), 1-16.

Rahima, A. (2017). Nilai Nilai Religius Seloko Adat Pada Masyarakat Melayu Jambi (Telaah Struktural Hermeneutik). Jurnal Ilmiah Universitas Batanghari ambi, 14(4), 1-8.

Rahima, A. (2018). Educational Character Values in Seloko Custom Utterances of Jambi Malay Society. KnE Social Sciences, 754763 
Siswantoro. (2010). Metode Analisis

Sastra Analisis Struktur Puisi.

Yogyakarta: Pustaka Belajar.

Nilai Pendidikan Karakter pada Karakter Tokoh Nadine Adella Ulani dalam Novel Alone Karya Chelsea Karina 